\title{
Influences of International Trade on China's Regional Economic \\ Development
}

\author{
Burenmende
}

\author{
School of Economics and Management, Inner Mongolia University \\ for the Nationalities, Tongliao, 028000, China
}

\begin{abstract}
With China global economic integration development after joining WTO, there is a closer and closer relation between China and world economy, and also bigger and bigger mutual influence. Under the condition of such chance and challenge, how to promote Chinese economy to realize a better development and occupy the dominating position of foreign trade is a main problem which shall be researched in terms of China's economic development; this paper gives a discussion on this problem.
\end{abstract}

Key words: international trade; regional economy; influence

\section{Introduction}

Currently, the world economy has gradually developed toward integrated and global direction; these two development directions supplement and promote each other, which shows the inevitability of social productive force. Meanwhile, it is also the essence of global economic trade development. As the economic trade is nationalized, the economic relation between different country and different region is enhanced; WTO plays an important role in standardizing the development order and operation mode of international trade and it promotes the global economy to develop toward a newer direction. Due to the fact that there exists great degree of limitation in multilateral trade, the bilateral trade has a rapid development, which is also a kind of effective promotion for integration of regional economy.

\section{Basic connotation of international trade}

The goods and service trading activities between a country and its regions are called 
national trade; this is a way which shows division of labor between a country and its regions; in terms of economy, it reflects the mutual dependence relation between country and region. The foreign trade refers to exchange activities which happen between one country and the regions of other country from perspective of one country. Based on international division of labor, the commodity exchange between one country and another country is called international trade. The international trade belongs to historical category and it is a product of human's productivity, and it is

continuously expanded with refining of social division of labor and continuous development of social productive force. The international trade belongs to specific economic production activities; with continuous progress in scientific and technological level, people's understanding of international trade changes to a great degree.

\section{Functions of international trade in regional economic development}

1. As for international trade, its most primitive function is to regulate supply and demand and realize mutual exchange of needed products. Due to limitations of development of productive force, there exists non-equivalence in each country's quality testing in commodity production and goods service; the goods and service which can't be produced or which are not suitable to be produced in one country can enter such country via foreign trade, and then the products and service which are suitable to be produced in such country can be exported to other country. To some degree, the international trade is favorable for meeting one country's demand and filling its gap, and it is of great significance for improving people's living level in this country.

2. The international trade can promote reasonable allocation and optimization of resources. The fundamental purpose of international trade is to obtain the maximum economic profit; through international trade, it is able to realize good circulation of resources and then realize optimization and allocation of each country's resources. In terms of resource allocation way, the direct foreign investment and import and export trade are good ways and methods. Through export of rich services and commodities and import of scare commodities of one country, it is able to realize new allocation 
and optimization of resources. Besides, the foreign commodities can be directly combined with domestic commodities via foreign fund, which is also one of ways of optimizing resource allocation. Although there will be different effect of resource allocation obtained between direct foreign investment and import and export trade, the effect of resource allocation is greatly related with economic technology level of one country to a great degree.

3. The good and ordered national economic trade can bring large-scale economic interests. Under current international trade development, the developed countries play a dominating role and they belong to the subject of international trade; the manufactured goods trade plays an object role in international trade. As for many industries, their technological objective requirement is to adopt the scale economy mode; the more inefficient one industry is, the bigger the scale is and the higher market requirement there is. Therefore, even for great power with great economic development, the industrial development can't completely depend on the support of domestic market. Under this condition, the foreign trade becomes important means and method in order to realize industrial scale economy development.

4. The balanced development of national economy depends on international trade. Under the condition of market economic development, there is not completely balanced development among all sectors and their sub-sectors of society. As for sectors with quick development, they need to exploit foreign market to realize the value of partial products; as for sectors with slow development, it is able to help them to make up the deficiencies in production and consumption materials in domestic production via actively developing foreign trade; it shall be noted that the international trade doesn't passively adapt to comprehensive balanced development of national economy. Furthermore, with constantly changing global economy, the comprehensive balance of national economy shall be realized via international economy; the macroeconomic decision-making ability of one country is highlighted via the functions exerted by its international trade to a great extent.

5. The international trade promotes effective improvement of economic profit. The profit of commodity is the balance between price and cost; through international trade, 
the price or cost of commodity will be affected. When there is no change in price of commodity, the reduction in cost of commodity can be realized via importing cheap production materials, which effectively improves the profit of commodity. When there is no change in cost of commodity, it is a kind of effective improvement for price and quality of commodity via importing high-quality commodity. When the imported goods are cheap and high-quality, the profit can be greatly improved. One country can obtain super profit via international trade; for example, if one country has a higher labor productivity in one commodity compared to other country, it means that this commodity has relative short production time compared to necessary labor time of international society; therefore, while this commodity is sold according to international market price, it is not paid as a product with high technology. Because it takes a long time to improve the level of productive force, the developed countries can occupy this super profit. In international trade, adopting monopoly means is also a means to obtain great economic source; however, in terms of essence, the monopoly is closely related to and tightly combined with labor productivity.

6. The international trade is of great significance for enhancing competitiveness and effectively improving national economic efficiency. The basic feature of market economy is competition. Compared to domestic competition, the international competition has a wider scope, deeper degree, and bigger effect. The international competition is good for enterprises to improve technology, improve operation management, reduce cost, and improve labor productivity so as to improve resource allocation efficiency and increase customers' welfare. Besides, the international competition is also a "sharp knife" which breaks the "ice" of domestic and foreign market monopoly.

7. Under some conditions, the backward countries can narrow the gap with developed countries via international trade, and this purpose can be easily realized via international trade. After World War II, the reason why Four Little Dragons in East Asia and Japan can quickly rise is that they develop foreign trade, that is to say, they play a role same as the role played by the countries which discovered the New World in early stage. However, due to limitations of many factors, there is no smooth sailing 
in the process that the foreign trade is used as economic growth point; as for one backward country which depends on foreign trade to obtain economic growth and then to surpass advanced countries, the limitation factors are also closely related with its trade strategy except for constraints of internal and external environmental conditions.

8. The political, economic and other diplomatic purposes can be realized via foreign trade. The international trade is not pure economic trade; to some degree, it stands for one country's diplomatic and political means. For example, over a long time, the western developed countries strictly control the input of advanced technology and high-tech products into communist countries via so-called “Coordinating Committee for Export to Communist Countries”, and the essence of this practice is to contain communist countries, and some developed countries even often implement trade embargo in order to force other countries to give in.

\section{Influences of international trade on China's regional economic development}

1. The international trade causes rapid-development economic globalization. The economic globalization progress is both a historic development and changing process, and also an economic spreading development process. To some degree, the closer relation between economic organizations of countries in the world is, the more profound mutual cooperation and influence is, and finally those countries will blend into integrated mode, and the so-called global market is formed. At another level, the standard economic behavior is established in global scope, and then the globalized economic operation strategy is established according to this global economic mechanism. In the economic globalization process, the international market has a rapid and large-scale development, and then the optimal allocation of resources and free circulation operation are realized as for various kinds of technologies and resources within this scope.

2. The international trade enhances free trade and effectively increases global welfare. Since the end of last century, with continuous deepening of international division of labor as well as leaping development of scientific and technological level, the economic trade has a widely globalized development from perspective of participating 
object and participating subject. From perspective of participating subject, most of countries have stretched out their economic tentacle to countries in the world in a passive or active way. From perspective of participating object, the big economy and trade concept is formed, and the trade is not merely trade of cargos, and it has developed to the trade in direct investment, finance, service, and other fields. The rapid-development trade globalization proves that the world market has been closely bound with each country's economy, and there is stronger and stronger mutual dependence and interaction. Therefore, the countries in the world shall remove the barriers which hinder national trade to maximum degree so as to optimize resource allocation in global scope and drive the increase of global welfare.

3. There is obvious integrated development of regional economy.

In order to effectively enhance economic cooperation and external competitiveness, the countries shall make intervention to realize collectivized region; through formulating corresponding treaties or agreements, it is able to form two or above countries in the region into an institution with super-country property; in terms of foreign trade policy, it is able to formulate uniform internal and external trade economy and fiscal policy so as to effectively eliminate the barriers which hinder the economic trade between countries in the region, realize mutual benefits, continuously optimize the resources in the region and promote the resources to realize harmonious development. The essence of regional economy is a kind of regional economic organization, such as APEC. Since the end of last century, various kinds of regional integrated organizations appear in the world, which causes diversified and liberalized economic trade phenomenon.

\section{Methods applied by China to develop regional economy under the condition of international economic trade}

1. To expand the research, and develop foreign trade via high-tech industry

In terms of export and import, it is able to utilize comparative advantage to realize their effective connection. It is required to capture China's advantages, tightly seize the strategic technology of multinational corporation and overflow effect of capital, and promote Chinese industries to realize leap-type development and reform; take 
industrial development as a basis to continuously exploit international market, continuously expand the international competitiveness of China's high-tech products, and continuously carry out industrial investment; know the fact that the industrial investment is a kind of great demand for key-technology products, and then expand the high-tech import.

2. To adopt diversified market strategy, and continuously expand China's trade space In terms of market exploitation, it is required to continuously perfect and implement import and export tax drawback, credit and loan, and other policies and means, and ensure stable drawback policy. The coverage area of export credit insurance shall be continuously expanded, more innovation is encouraged for trade financing products, and the continuous attention shall be paid to insurance policy financing problem. It is required to enhance the management on export tax drawback and other business, and enhance support on middle and small-sized enterprises' import and export credit and loan; improve the service level of quality control, foreign exchange, customs, and other department, and continuously improve the convenient level of trade; implement diversified market strategy, continuously enhance and consolidate the traditional market with European and American countries, and continuously expand the new market in Southeast Asia and Latin America. Furthermore, it is required to adopt high-quality strategy to win the victory, improve the market competitiveness of export products, and continuously improve the original low-price and low-cost competition mode to practically improve core competitiveness. In terms of development of China's regional economy, the attention shall be also paid to foreign exhibition platform, and it is required to continuously enhance the way of participating in exhibition of middle and small-sized enterprises and then expand their market.

3. To enhance the protection of international trade law on international trade

As is known to us, the impact and damage caused by new trade protectionism on international trade are inestimable, thus China shall issue some policies or adopt necessary active measures to participate in the formulation of international trade rules. As for rightful trade rights, China shall maintain them to effectively avoid the situation that some main trade cooperation countries use trade rules to implement new 
trade protectionism; as for international trade as well as management and operation activities of economic trade organizations, China shall actively participate in them to keep the stability of international trade organizations and enhance negotiation and cooperation relationships with trade partners. As for some partners' monopoly behaviors in some ideology fields, it is required to weaken or prevent them, firmly restrain the attempt that some countries utilize human rights, democracy and other tools to implement new trade protection, and continuously improve China's deficiencies based on those problems.

\section{Conclusion}

In a word, under the condition of global economic development, the new development trend in international trade is the product of economic integration, which is also the condition and basis of economic globalization. The increasing development of international trade can also effectively drive global economy, and the interaction of various factors can produce great influence. Therefore, under such condition, China shall follow the basic rules of economic development, and find out the strategies which are suitable for China's foreign trade to promote significant development of China's foreign trade so as to obtain big economic benefit.

\section{References}

[1] Ye Qingyan: China's International Trade Environment and Countermeasures [J], Theoretical Review, 2014, (02): 59-61.

[2] Liang Kaiming: China’s Foreign Trade Situation and Expectation under Condition of Economic Globalization [J], China Circulation Economics, 2012 (09): 87-89.

[3] Wang Shuangping: Discussion on International Trade Friction under Economic

Globalization [J], Journal of Liaoning Radio and TV University, 2011 (22): 123-125. 